\title{
KEKUATAN HUKUM PENYELESAIAN SENGKETA WARIS MELALUI MEDIATOR TOKOH MASYARAKAT DI DESA WONOSALAM KECAMATAN WONOSALAM KABUPATEN DEMAK
}

\author{
Ahmad Falih Mahruz \\ MAS Nahdlatul Ulama Karangrowo Wonosalam Demak. Email: \\ falihmahruz@gmail.com

\begin{abstract}
This article is a field research to answer the role of community leaders as mediators in the settlement of inheritance disputes in Wonosalam, Demak and how the legal power of resolving inheritance disputes through mediator community leaders in Wonosalam, Demak. Research data are collected through interviews and observations, then are analyzed with descriptive analytical techniques with inductive thought pattern. Wonosalam community leaders have an important role in the settlement of inheritance disputes, namely as a mediator, including: opening and leading the mediation process, explaining and determining the heirs' parts, providing the best advice and solutions, deciding and determining what has been agreed by the parties to the dispute, preventing the emergence of even bigger disputes, and still maintaining harmony and harmony in social life. The results of the settlement of inheritance disputes through mediators of community leaders in Wonosalam do not have an enforceable legal force, because they are not confirmed by making a peace certificate or a peace agreement letter, which is contained in: article 27 of the Supreme Court Regulation No. 1 of 2016 concerning Mediation Procedures and article 1851 Civil Code. Nevertheless, the determination of community leaders as mediators in the settlement of inheritance disputes is obeyed and implemented by the people of Wonosalam.
\end{abstract}

Keywords: Settlement of inheritance disputes and mediators of community leaders.

Abstrak: artikel ini adalah hasil penelitian lapangan untuk menjawab bagaimana peran tokoh masyarakat sebagai mediator dalam penyelesaian sengketa waris di Desa Wonosalam Kecamatan Wonosalam Kabupaten Demak dan bagaiamana kekuatan hukum penyelesaian sengketa waris melalui mediator tokoh masyarakat Desa Wonosalam Kecamatan Wonosalam Kabupaten Demak. Data penelitian dihimpun melalui wawancara dan observasi, dianalisis dengan teknik deskriptif analitis dengan pola pikir induktif. Tokoh masyarakat Desa Wonosalam memiliki peran penting dalam penyelesaian sengketa waris, yaitu sebagai mediator, diantaranya: membuka dan memimpin proses mediasi, menjelaskan dan menentukan bagian-bagian ahli waris, memberikan nasihat dan solusi yang terbaik, memutuskan dan menetapkan apa yang telah disepakati para pihak yang bersengketa, mencegah timbulnya sengketa yang lebih besar lagi, dan tetap menjaga kerukunan dan keharmonisan dalam hidup bermasyarakat. Hasil penyelesaian sengketa waris melalui mediator tokoh masyarakat di

AL-HUKAMA

The Indonesian Journal of Islamic Family Law Volume 09, Nomor 01, Juni 2019; ISSN:2089-7480 
Desa Wonosalam tersebut tidak mempunyai kekuatan hukum yang eksekutorial, karena tidak dikukuhkan dengan pembuatan akta perdamaian ataupun surat perjanjian perdamaian sesuai pasal 27 Peraturan Mahkamah Agung Nomor 1 Tahun 2016 tentang Prosedur Mediasi dan pasal 1851 KUH Perdata. Meski demikian, ketetapan tokoh masyarakat sebagai mediator dalam penyelesaian sengketa waris tersebut dipatuhi dan dilaksanakan oleh masyarakat Desa Wonosalam.

Kata Kunci: Penyelesaian sengketa waris dan mediator tokoh masyarakat.

\section{Pendahuluan}

Masalah waris, sering menjadi sumber sengketa dalam keluarga. Terutama untuk menentukan siapa saja yang berhak dan tidak berhak mendapat warisan yang pada gilirannya bisa menimbulkan keretakan keluarga. Menurut salah satu pihak dianggap sudah adil sedang menurut pihak lain masih menganggap tidak adil. Keadilan menurut pemikiran manusia sangat subjektif. Karena itu, agama Islam datang membawa ketentuan-ketentuan dari Allah Swt. dalam hal waris mewarisi ini. Sehingga apabila orang-orang telah dilandasi ketakwaan kepada Allah Swt. semuanya akan berjalan dengan lancar, tidak akan menimbulkan sengketa lagi, bahkan kerukunan keluarga pun akan tercapai.

Dalam Islam dikenal adanya tahkim, dalam ensiklopodi hukum Islam, tahkim adalah berlindungnya dua pihak yang bersengketa kepada orang yang mereka sepakati dan disetujui serta rela menerima keputusannya untuk menyelesaikan persengketaan mereka.

Penyelesaian sengketa melalui mediasi sudah dikenal sejak zaman dahulu, beberapa daerah di Indonesia sudah melaksanakannya.1 Penggunaan mediasi dalam sistem hukum di Indonesia, selain didasarkan pada kerangka peraturan perundangundangan negara, juga dipraktikkan dalam penyelesaian sengketa dalam lingkup masyarakat adat atau sengketa-sengketa dalam

1Mediasi adalah cara penyelesaian sengketa melalui proses perundingan untuk memperoleh kesepakatan Para Pihak dengan dibantu oleh Mediator.(pasal 1 ayat 1 Peraturan Mahkamah Agung No 1 Tahun 2016 Tentang Prosedur Mediasi). 
masyarakat pada umumnya, seperti permasalahan keluarga, waris, batas tanah, dan masalah-masalah perdata lainnya.2

Awal perkembangan penggunaan mediasi, mediator bukanlah sebuah profesi atau pekerjaan, tetapi mediator dilakukan oleh tokohtokoh dalam masyarakat. Dalam konteks masyarakat tradisional atau masyarakat adat, mediator diperankan oleh kepala desa, kepala suku, fungsionalis adat atau tokoh agama.3

Sampai sekarang ini, masih ada masyarakat yang memilih menyelesaikan sengketa melalui proses non-litigasi khususnya masyarakat desa dalam menyelesaikan permasalahan keluarga. Ada beberapa faktor yang mempengaruhi masyarakat enggan menyelesaikan masalahnya menggunakan proses peradilan. Diantaranya mereka beranggapan, apabila masalah mereka diselesaikan di pengadilan mereka merasa kesulitan mengurusi dan mengikuti prosedur yang ada di pengadilan dan akan memakan biaya yang tidak sedikit.

Hal-hal inilah yang membuat mereka lebih memilih menyelesaikan masalah mereka dengan bermediasi secara nonlitigasi. Selain itu, bermediasi secara non-litigasi dirasa cukup menyelesaikan masalah mereka dengan memanfaatkan peran tokoh masyarakat seperti tokoh agama, perangkat desa ataupun orang yang dituakan di lingkungan masyarakat sebagai mediator dalam masalah mereka.

Sama halnya yang terjadi pada masyarakat di Desa Wonosalam Kecamatan Wonosalam Kabupaten Demak, apabila terjadi masalah keluarga, mereka lebih memilih menyelesaikannya secara kekeluargaan terlebih dahulu sebagaimana disebutkan pada ketentuan pasal 183 Kompilasi Hukum Islam yang menyatakan: bahwa para ahli waris dapat bersepakat melakukan perdamaian dalam pembagian harta warisan setelah masing-masing menyadari bagiannya.4 Kemudian dalam pasal 1851 BW juga dinyatakan, bahwa perdamaian adalah suatu perjanjian, dengan mana kedua belah pihak, dengan menyerahkan, menjanjikan atau menahan suatu

2Takdir Rahmadi, Mediasi Penyelesaian Sengketa Melalui Pendekatan Mufakat (Jakarta: Raja Grafindo Persada, 2011), 70.

3Ibid., 35.

4Tim Nuansa Aulia, Kompilasi Hukum..., 55. 
barang, mengakhiri suatu perkara yang sedang bergantung ataupun mengakhiri suatu perkara. Perjanjian ini tidaklah sah, melainkan dibuat secara tertulis. 5

Apabila mereka tidak mendapatkan titik temu dari permasalahan tersebut mereka lebih memilih untuk datang pada tokoh masyarakat yang mereka yakini mampu menyelesaikan masalah mereka. Sepengetahuan penulis, tidak ada tahapan tertentu kepada siapa mereka menentukan tokoh masyarakat yang akan mereka jadikan penengah atau rujukan dalam masalah mereka, ada sebagian dari mereka datang ke RT/RW terlebih dahulu dan ada yang memilih langsung datang ke tokoh masyarakat.

Masyarakat Desa Wonosalam tergolong dalam masyarakat yang kental dengan agama dan paham mengenai hukum Islam, akan tetapi meskipun mereka paham dengan agama banyak dari mereka lebih memilih tokoh agama (kiyai) mereka dalam menyelesaikan masalah mereka, salah satunya dalam kasus waris. Tokoh agama (kiyai) yang mereka pilih adalah sesuai dengan kepada siapa mereka dulu mereka ngaji (mencari ilmu). Banyak tokoh agama yang bisa dijadikan penengah dalam menyelesaikan masalah mereka. Karena di desa ada 5 pondok pesantren yaitu Pesantren Al-Mujtahid, Pesantren Al-Jalil, Pesantren Al-Huda, Pesantren Nurul Furqon, dan Pesantren AsSidqiyyah serta masih banyak lagi kiai-kiai kampung yang paham dengan agama dan mampu menyelesaikan masalah mereka.6

Dalam pembagian harta peninggalan/waris masyarakat Desa Wonosalam ada yang dibagikan sebelum pewaris meninggal dunia atau hibah, 7 dan ada pula yang pula yang dibagikan setelah pewaris meninggal dunia dan dilakukan secara kekeluargaan setelah proses perawatan pewaris atau si mayit, seperti biaya pemakaman dan pengajian sampai tujuh hari, hutang pewaris. Pihak keluarga atau ahli waris dikumpulkan dan dihitung berapa jumlah ahli warisnya untuk diadakan penyelesaian pembagian waris tersebut. Kemudian

5Subekti dan Tjitrosudibio, Kitab Undang-undang Hukum Perdata (Jakarta: Pradnya Paramita, 1985), 420.

6Royan (Sekertaris Desa), Wawancara, Demak, 24 September 2018.

7 Hibah adalah pemberian suatu benda secara sukarela dan tanpa imbalan dari seseorang kepada orang lain yang masih hidup untuk dimiliki. (pasal 171 huruf $g$ Kompilasi Hukum Islam). 
dijumlah berapa harta yang bisa dibagi setelah dipergunakan untuk kepentingan pewaris.

Apabila terjadi perselisihan antara ahli waris yang tidak dapat diselesaikan dengan musyawarah keluarga, mereka tidak mengajukan sengketa kewarisan ke Pengadilan Agama. Masyarakat lebih memilih menyelesaikannya melalui tokoh mayarakat dan kemudian diadili dan diputuskan tokoh masyarakat.8 Adapun mengenai hasil dari kesepakatan yang dihasilkan dari mediasi oleh tokoh masyarakat tersebut tidak dibuatkan suatu surat perdamaian dari mediasi yang telah selesai, masyarkat secara suka rela menerima dan menjalankan kesepakatan yang telah disepakati bersama dalam proses mediasi yang telah diputuskan.

Dari paparan di atas, penulis tergugah untuk meneliti lebih detail lagi terkait kekuatan hukum dari hasil penyelesaian sengketa waris melalui tokoh masyarakat sebagai mediatornya yang telah penulis rangkai dengan judul Kekuatan Hukum Penyelesaian Sengketa Waris Melalui Mediator Tokoh Masyarakat (Studi Kasus di Desa Wonosalam Kecamatan Wonosalam Kabupaten Demak). Penulis akan menuangkan hasil penelitiannya ke dalam sebuah karya tulis berbentuk penelitian.

\section{Mediasi Menurut Peraturan Mahkamah Agung Nomor 1 Tahun 2016 Tentang Prosedur Mediasi}

1. Pengertian Mediasi dan Mediator

Secara etimologi istilah mediasi berasal dari bahasa latin, mediare yang berarti berada di tengah. Makna ini merujuk pada peran yang ditampilkan pihak ketiga sebagai tugasnya yaitu menengahi dan menyelesaikan sengketa antar pihak."Berada di tengah" juga berarti mediator harus berada pada posisi netral dan tidak memihak dalam menyelesaikan dan menengahi perkara. Ia harus mampu menjaga kepentingan pihak bersengketa secara adil sehingga menumbuhkan kepercayaan (trust) dari para pihak yang bersengketa.9

8Jalil, Wawancara, Demak, 15 September 2018.

9 Syahrizal Abbas, Mediasi Dalam Perspektif Hukum Syariah, Hukum Adat, dan

Hukum Nasional, cet.1 (Jakarta: Kencana Prenada Media, 2009), 1-2. 
Secara umum, dalam Kamus Besar Bahasa Indonesia, yang dimaksud dengan mediasi adalah proses pengikutsertaan pihak ketiga dalam menyelesaikan suatu perselisihan sebagai penasehat.10 Di Indonesia, pengaturan tentang mediasi di pengadilan, terdapat dalam Peraturan Mahkamah Agung Nomor 2 Tahun 2003 yang kemudian diubah dengan Peraturan Mahkamah Agung Nomor 1 Tahun 2008 yang kemudian disempurnakan dengan Peraturan Mahkamah Agung Nomor 1 Tahun 2016 tentang Prosedur Mediasi di Pengadilan. Peraturan Mahkamah Agung tersebut dimaksudkan dalam rangka mengembangkan dan melembagakan mediasi dalam konteks perdamaian di pengadilan.

Dalam konteks mediasi di Pengadilan, pengertian mediasi dijelaskan dalam pasal 1 angka 6 Peraturan Mahkamah Agung Nomor 2 Tahun 2003 yang menyatakan, bahwa mediasi adalah penyelesaian sengketa melalui proses perundingan para pihak dengan dibantu oleh mediator.11 Sedangkan dalam pasal 1 ayat 7 Peraturan Mahkamah Agung Nomor 1 Tahun 2008 terdapat pengertian mediasi yang menyatakan, bahwa mediasi adalah cara penyelesaian sengketa melalui proses perundingan untuk memperoleh kesepakan para pihak dengan dibantu oleh Mediator".12

Begitu juga dalam Peraturan Mahkamah Agung No.1 Tahun 2016 pasal 1 ayat 1 dijelaskan, bahwa mediasi adalah cara penyelesaian sengketa melalui proses perundingan untuk memperoleh kesepakatan para pihak dengan dibantu oleh mediator.13 Selanjutnya, dalam pasal 1 ayat 2 dijelaskan bahwa mediator itu sendiri adalah hakim atau pihak lain yang memiliki sertifikat mediator sebagai pihak netral yang membantu para

10 Tim Penyusun Kamus Pusat Bahasa, Kamus Besar Bahasa Indonesia, cet.2 (Jakarta: Balai Pustaka, 2002), 726.

11 Rachmadi Usman, Pilihan Penyelesaian Sengketa di Luar Pengadilan(Bandung: PT. Citra Aditya Bakti, 2003), 79.

12Pasal 1 ayat 7 Peraturan Mahkamah Agung Nomor 1 Tahun 2008 tentang Prosedur Mediasi.

13Pasal 1 Peraturan Mahkamah Agung Nomor 1 Tahun 2016 tentang Prosedur Mediasi. 
pihak dalam proses perundingan, guna mencari berbagai kemungkinan penyelesaian sengketa tanpa menggunakan cara memutus atau memaksakan sebuah penyelesaian.14

Dari beberapa pengertian di atas dapat ditarik kesimpulan, bahwa ada beberapa unsur penting dalam mediasi, antara lain sebagai berikut:

a. Mediasi adalah proses penyelesaian sengketa berdasarkan perundingan

b. Mediator terlibat dan diterima para pihak yang bersengketa didalam perundingan

c. Mediator bertugas membantu para pihak yang bersengketa untuk mencari penyelesaian.

d. Mediator tidak mempunyai kewenangan membuat keputusan selama perundingan berlangsung.

Tujuan mediasi adalah untuk mencapai atau menghasilkan kesepakatan yang diterima pihak-pihak yang bersengketa guna mengakhiri sengketa. 15

Sebagai seorang mediator yang dituntut untuk mengedepankan negosiasi yang bersifat kompromis, hendaklah memiliki ketrampilan-ketrampilan khusus.ketrampilan khusus yang dimaksud ialah:

a. Mengetahui bagaimana cara mendengarkan para pihak yang bersengketa.

b. Mempunyai ketrampilan bertanya terhadap hal-hal yang dipersengketakan.

c. Mempunyai ketrampilan membuat pilihan-pilihan dalam menyelesaikansengketa yang hasilnya akan menguntungkan para pihak yang bersengketa (win-win solution).

d. Mempunyai ketrampilan tawar menawar secara seimbang.

e. Membantu para pihak untuk menemukan solusi mereka sendiri terhadap hal-hal yang dipersengketakan.16

14Ibid.

15 Suyut Margono, ADR dan Arbitrase Proses Pelembagaan dan Aspek Hukum (Bogor: PT.Graha Indonesia, 2000), 59.

16 Harijah Darmis, "Hukum Mediasi Versi Sema Nomor 1 Tahun 2002 tentang Pemberdayaan Pengadilan Tingkat Pertama Menerapkan Lembaga Damai", Mimbar Hukum, No. 63. (Maret-April 2004), 28. 


\section{Prinsip-Prinsip Mediasi}

Berikut ini adalah prinsip-prinsip yang digunakan dalam praktik mediasi, yaitu:

a. Bersifat sukarela

Pengertian sukarela disini artinya para pihak yang bersengeketa datang ke mediasi atas keinginan mereka sendiri secara sukarela. Prinsip kesukarelaan dibangun atas dasar bahwa orang akan mau bekerja sama untuk menemukan jalan keluar dari persengketaan. Sifat sukarela tersebut didukung fakta bahwa mediator yang menengahi sengketa para pihak hanya memiliki peran untuk membantu para pihak menemukan solusi yang terbaik atas sengketa yang dihadapi.

b. Lingkup sengketa bersifat keperdataan

Jika dilihat dari berbagai peraturan setingkat UndangUndang yang mengatur tentang mediasi di Indonesia dapat disimpulkan bahwa pada prinsipnya sengketa-sengketa yang dapat diselesaikan melalui mediasi adalah sengketa keperdataan.

c. Proses sederhana

Para pihak dapat menentukan cara-cara yang lebih sederhana dibandingkan dengan proses beracara formal di Pengadilan. Jika penyelesaian sengketa melalui litigasi dapat selesai bertahun-tahun, jika kasus terus naik banding, kasasi, sedangkan pilihan penyelesaian sengketa melalui mediasi lebih singkat, karena tidak terdapat banding atau bentuk lainnya.Putusan bersifat final and binding yang artinya putusan tersebut bersifat inkracht atau mempunyai kekuatan hukum yang tetap.

d. Proses mediasi tetap menjaga kerahasiaan sengketa para pihak

Mediasi dilaksanakan secara tertutup sehingga tidak setiap orang dapat menghadiri sesi-sesi perundingan mediasi.Hal ini berbeda dengan badan peradilan dimana sidang umumnya dibuka untuk umum. Sifat kerahasiaan dari proses mediasi merupakan daya tarik tersendiri, karena para 
pihak yang bersengketa pada dasarnya tidak suka jika persoalan yang mereka hadapi dipublikasikan kepada umum.

e. Mediator bersifat menengahi

Dalam sebuah proses mediasi, mediator menjalankan peran untuk menengahi para pihak yang bersengketa. Peran ini diwujudkan melalui tugas mediator yang secara aktif membantu para pihak dalam memberikan pemahaman yang benar tentang sengketa yang mereka hadapi dan memberikan alternatif solusi yang terbaik bagi penyelesaian sengketa tersebut.17

3. Peran dan Fungsi Mediator

Peran penting seorang mediator dapat digambarkan sebagai berikut:

a. Mediator harus berada di tengah para pihak, mediator bertindak sebagai pihak ketiga yang menempatkan diri benar-benar di tengah para pihak.

b. Mengisolasi proses mediasi, mediator tidak berperan sebagai hakim yang bertindak menentukan pihak mana yang salah dan benar, bukan pula bertindak dan berperan sebagai pemberi nasihat hukum (to give legal advice), juga tidak mengambil peran sebagai penasihat hukum (counsellor) atau mengobati (the rapits) melainkan hanya berperan sebagai penolong (helper flore).

c. Mediator harus mampu menekan reaksi. Dalam point ini seorang mediator harus mampu berperan untuk menghargai apa saja yang dikemukakan kedua belah pihak, ia harus menjadi seorang pendengar yang baik, mampu mengontrol kesan buruk sangka, mampu berbicara dengan terang dengan bahasa yang netral, mampu menganalisa dengan cermat fakta persoalan yang kompleks serta mampu berpikir di atas pendapat sendiri.

d. Mampu mengarahkan pertemuan pemeriksaan. Sedapat mungkin pembicaraan pertemuan tidak melentur dan menyinggung serta mampu mengarahkan secara langsung kearah pembicaraan ke arah pokok penyelesaian.

${ }_{17}$ Whimbo Pitoyo, Strategi Jitu Memenangi Perkara Perdata Dalam PraktikPeradilan(Jakarta: Visimedia, 2012), 3-7. 
e. Pemeriksaan bersifat konfidensi. Segala sesuatu yang dibicarakan dan dikemukakan oleh para pihak harus dianggap sebagai informasi rahasia (convidentil information), oleh karena itu mediator harus memegang teguh kerahasiaan persengketaan maupun identitas pihak-pihak yang bersengketa.

f. Hasil kesepakatan dirumuskan dalam bentuk kompromis (compromise solution). Kedua belah pihak tidak ada yang kalah dan tidak ada yang menang, tetapi sama-sama menang (winwin). 18

Fungsi mediator adalah sebagai penengah dan harus netral. Karena jika mediator bersikap netral, maka akan lahir ikatan berdasarkan kepercayaan. Mediator ini berkewajiban untuk melaksanakan tugas dan fungsinya berdasarkan kehendak dan kemauan para pihak. Mediator juga harus mampu menciptakan situasi dan kondisi yang kondusif bagi terciptanya kompromi diantara kedua belah pihak yang bersengketa untuk memperoleh hasil yang saling menguntungkan (win-win).

Selain itu mediator juga bertujuan menolong dua belah pihak untuk mencapai kesepakatan dengan tetap netral dan menjamin kerahasiaan para pihak tidak merasa kehilangan, walaupun harus mengurangi hal yang menguntungkan mereka untuk mencapai kesepakatan.19

4. Prosedur Mediasi

Mediasi dikatakan berhasil atau tidak dapat dilihat dari proses atau tahapan dari mediasi tersebut. Apabila mediasi dilakukan dengan baik dan benar maka hasil yang didapatkan akan baik, begitupun apabila mediasi dilakukan dengan tidak baik maka hasil yang didapatkan akan tidak baik atau bahkan gagal.

Mengenai prosedur berperkara, sangat penting untuk diketahui, dengan mengetahui prosedur berperkara para pihak

18Restiana, "Penyelesaian Sengketa Tanah Warisan Melalui Mediasi, Studi Kasus diPengadilan Agama Watampone Kelas 1B"(Penelitian--UINAlauddin, Makasar, 2016), 20.

19 Yusna Zaidah, Penyelesaian Sengketa Mealui Peradilan dan Arbirtase Syariah diIndonesia, cet.2 (Yogyakarta: Aswaja Pressindo, 2015), 28- 29. 
akan tahu apa yang akan dilakukannya, karena para pihak umumnya belum terbiasa dengan aturan hukum yang berlaku. Dengan ini perlu diketahui prosedur atau tahapan beracara mediasi, adapun tahapan dalam mediasi yaitu:20

a. Tahap pra mediasi

Pada hari sidang pertama yang dihadiri kedua belah pihak hakim mewajibkan para pihak untuk menempuh mediasi. Hakim menunda proses persidangan persidangan perkara untuk memberikan kesempatan proses mediasi lama 30 hari kerja. Hakim menjelaskan prosedur mediasi kepada para pihak yang bersengketa. Para pihak memilih mediator dari daftar nama yang telah tersedia pada hari sidang pertama atau paling lama 2 hari kerja berikutnya. Apabila dalam jangka waktu tersebut dalam point 4 para pihak tidak dapat memilih mediator yang dikehendaki. Ketua majelis hukum segera menunjuk hakim bukan pemeriksa pokok perkara untuk menjalankan fungsi mediator.

b. Tahap proses mediasi

Tahap Proses Mediasi merupakan tahapan yang bersifat informal dalam arti tidak secara berurutan diatur di dalam Peraturan Mahkamah Agung Nomor 1 Tahun 2016, namun ada beberapa tahapan yang secara kebiasaan dilakukan. Dalam waktu paling lama 5 hari kerja setelah para pihak menunjuk mediator yang disepakati, masing-masing dapat menyerahkan resume perkara.kepada hakim mediator yang ditunjuk. Proses mediasi berlangsung paling lama 30 hari kerja sejak penetapan perintah melakukan mediasi.21Mediator berkewajiban menyatakan mediasi telah gagal jika salah satu pihak atau para pihak telah 2 kali berturut-turut tidak menghadiri pertemuan mediasi sesuai jadwal yang disepakati tanpa alasan setelah dipanggil secara patut.

c. Mediasi mencapai kesepakatan

20Pasal 1 ayat 1 Peraturan Mahkamah Agung Nomor 1 Tahun 2016 tentang Prosedur Mediasi.

21Pasal 1 ayat 1 Peraturan Mahkamah Agung Nomor 1 Tahun 2016 tentang Prosedur Mediasi. 
Jika mediasi menghasilkan kesepakatan perdamaian maka wajib dirumuskan secara tertulis dan ditandatangani oleh para pihak dan mediator.Jika mediasi diwakili oleh kuasa hukum maka para pihak wajib menyatakan secara tertulis persetujuan ya ng dicapai.Para pihak wajib menghadap kembali kepada hakim pada sidang yang telah ditentukan untuk memberitahukan kesepakatan perdamaian kepada hakim untuk dikuatkan dalam bentuk akta perdamaian.

d. Mediasi tidak mencapai kesepakatan

Jika mediasi tidak mencapai kesepakatan, mediator wajib menyatakan secara tertulis proses mediasi telah gagal. Pada tiap tahapan pemeriksaan perkara hakim pemeriksa perkara tetap berwenang untuk mengusahakan perdamaian hingga sebelum pengucapan putusan. Jika mediasi gagal, pernyataan dan pengakuan para pihak dalam proses mediasitidak dapat digunakan sebagai alat bukti dalam proses persidangan.

\section{Perjanjian Perdamaian dalam Hukum Perdata}

Kata perdamaian berarti penghentian permusuhan, tidak bermusuhan, keadaan tidak bermusuhan, berbaik kembali, tenteram aman. Berdamai, artinya berbaik kembali, berunding untuk menyelesaikan perselisihan. Mendamaikan atau memperdamaikan, artinya menyelesaikan permusuhan, merundingkan supaya mendapat persetujuan.22

Definisi lain dari perdamaian adalah persetujuan dengan mana kedua belah pihak atas dasar saling pengertian, mengakhiri suatu perkara yang sedang berlangsung atau mencegah timbulnya suatu sengketa. Jadi, dalam perjanjian ini, kedua belah pihak harus melepaskan sebagian tuntutan mereka dengan tujuan untuk mencegah timbul masalah. Perjanjian ini disebut perjanjian formal dan harus tertulis agar sah dan bersifat mengikat menurut suatu formalitas tertentu.23 Oleh karena itu harus ada timbal balik pada

22 Poerwadarminta, Kamus Umum Bahasa Indonesia (Jakarta: Balai Pustaka, 2005), 259

23 Subekti, Aneka Perjanjian(Bandung: PT. Citra Aditya Bakti, 1995), 177. 
pihak-pihak yang berperkara. Tidak ada perdamaian apabila salah satu pihak dalam satu perkara mengalah seluruhnya dan mengakui tuntutan pihak lawan seluruhnya.24

Perjanjian perdamaian disebut juga dengan istilah dading yang secara yuridis diatur dalam pasal 1851 sampai pasal $1864 \mathrm{KUH}$ Perdata. Pasal 1851 merumuskan perdamaian, yaitu suatu persetujuan dengan mana kedua belah pihak, dengan menyerahkan, menjanjikan atau menahan suatu barang, mengakhiri suatu perkara yang sedang bergantung ataupun mencegah timbulnya suatu perkara. Menurut Subekti, perdamaian merupakan perjanjian formal, karena diadakan menurut suatu formalitas tertentu, bila tidak maka perdamaian tidak mengikat dan tidak sah.25

Adapun unsur perdamaian beserta syarat dari unsur tersebut terdapat dalam KUHPerdata pasal 1851 dan 130 HIR. Dari kedua pasal tersebut terdapat empat unsur, yaitu:

1. Persetujuan kedua belah pihak

2. Mengakhiri sengketa

3. Perdamaian atas sengketa yang ada

4. Bentuk perdamaian harus tertulis

Selanjutnya menurut pasal 1852 ayat $1 \mathrm{KUH}$ Perdata menyatakan:

"Untuk mengadakan suatu perdamaian diperlukan bahwa seorang mempunyai kekuasaan untuk melepaskan haknya atas hal-hal yang termaktub di dalam perdamaian itu.

Ketentuan ini biasanya ditafsirkan, bahwa dading tidak boleh diadakan mengenai kedudukan orang-orang dalam Hukum Perseorangan atau kekeluargaan, misalnya tidaklah boleh diadakan dading tentang sah atau tidaknya suatu perkawinan, pengesahan seorang anak, sahnya suatu pengakuan sebagai anak. Juga hak-hak ketatanegaraan tidak boleh dimasukkan dalam dading, seperti misalnya hak untuk memilih atau dipilih menjadi anggota Badanbadan Perwakilan Rakyat.26

24 Victor M. Situmorang, Perdamaian dan Perwasitan dalam Hukum Acara Perdata (Jakarta: Rineka Cipta, 1993), 3.

25 Subekti, Aneka Perjanjian..., 177-178.

26 Wirjono Prodjodikoro, Hukum Perdata Tentang Persetujuan-Persetujuan Tertentu (Bandung:Vorkink Van Hoeve, 1959), 153. 
Dalam pasal 1853 ayat1 KUH Perdata menyatakan:

"Tentang kepentingan-kepentingan keperdataan yang terbit dari suatu kejahatan atau pelanggaran, dapat diadakan perdamaian."

Mengenai hal ini Subekti menjelaskan, tindak pidana yang akibat keperdataannya seringkali diselesaikan dengan perdamaian adalah tindak pidana "penggelapan", di mana diadakan perdamaian antara si pembuat dan perusahaannya untuk mengembalikan uang yang telah digelapkan, atau juga pelanggaran lalu lintas di mana seringkali diadakan perdamaian antara si pembuat dan pihak yang menderita kerugian. Memanglah banyak tindak pidana mempunyai segi keperdataan, yang merupakan "perbuatan melanggar hukum" yang memberikan hak kepada pihak yang dirugikan untuk menuntut penggantian kerugian.27

Selanjutnya pasal 1854 KUH Perdata, menentukan:

"Setiap perdamaian hanya terbatas pada soal yang termaktub didalamnya; pelepasan segala hak dan tuntutan yang dituliskan didalamnya harus diartikan sekedar hak-hak dan tuntutantuntutan itu ada hubungannya dengan perselisihan yang menjadi lantaran perdamaian tersebut." 28

Kemudian dalam pasal 1855 KUH Perdata juga menentukan:

"Setiap perdamaian hanya mengakhiri perselisihan-perselisihan yang termaktub didalamnya, baik para pihak merumuskan maksud mereka dalam perkataan khusus atau umum, maupun maksud itu dapat disimpulkan sebagai akibat mutlak satusatunya dari apa yang dituliskan".29

Kedua pasal tersebut bermaksud untuk memperingatkan supaya berlakunya perdamaian tidak diperluas hingga melampaui batas-batas persoalan yang telah diselesaikan dengan mengadakan perdamaian tersebut, Untuk mengetahui batas-batas itu setepatnya, kita harus selalu berpangkal pada soal-soal yang menjadi perselisihan, yang menyebabkan diadakannya perdamaian itu.

Mengenai kekuatan hukum perjanjian perdamaian, pasal 1858 ayat $1 \mathrm{KUH}$ Perdata menyebutkan : "Segala perdamaian mempunyai

27 Subekti, Aneka Perjanjian..., 179.

28 Subekti dan Tjitrosudibio, Kitab Undang-undang Hukum Perdata..., 420. 29Ibid. 
di antara para pihak suatu kekuatan seperti suatu putusan hakim dalam tingkat yang penghabisan”. Dengan demikian perdamaian itu tidak dapat dibantah dengan alasan kekhilafan mengenai hukum ataudengan alasan bahwasalah satu pihak dirugikan.30

Menurut KUH Perdata perjanjian perdamaian dapat dibatalkan dalam keadaan tertentu yaitu:

1. Pasal 1859, apabila telah terjadi suatu kekhilafan mengenai orangnya, atau mengenai pokok perselisihan. Ia dapat dibatalkan dalam segala hal di mana telah dilakukan penipuan atau paksaan. Jadi ketentuan ini memberikan kemungkinan membatalkan suatu dading berdasar atas salah pengertian mengenai orangnya subyek persetujuan, juga salah pengertian mengenai soal perselisihan sebagai daya penghalang sahnya suatu dading.

2. Pasal 1860, apabila telah terjadi kesalahpahaman tentang duduk perkaranya, mengenai suatu alas hak yang batal.

3. Pasal 1861, apabila suatu perdamaian didasarkan atas surat-surat yang kemudian dinyatakan palsu.

4. Pasal 1862, suatu perdamaian mengenai suatu sengketa, yang sudah diakhiri dengan suatu putusan hakim yang telah memperoleh kekuatan mutlak, namun tidak diketahui oleh para pihak atau salah satu dari mereka.

5. Pasal 1863, jika setelah perdamaian tentang segala urusan bagi kedua belah pihak diadakan, kemudian diketemukan surat-surat yang waktu itu tidak diketahui karena disembunyikan oleh salah satu pihak mengenai suatu urusan saja.31

\section{Penyelesaian Sengketa Waris Oleh Mediator Tokoh Masyarakat Desa Wonosalam Kecamatan Wonosalam Kabupaten Demak}

Ada dua macam penyelesaian perkara dalam pembagian harta warisan yang diajukan kepada bapak Abdul Fattah sebagai salah satu tokoh masyarakat Desa Wonosalam. Pertama, perkara yang diajukan tanpa didahului adanya suatu sengketa antara ahli waris. Kedua, perkara yang diajukan didahului adanya sengketa antara ahli waris.32

30Ibid., 421.

31Ibid., 421-422.

32Ibid. 
Dalam sepuluh tahun belakangan ini bapak Abdul Fattah menyelesaikan lima perkara masalah pembagian harta warisan. Dalam menyelesaikan sengketa waris beliau sesuai dengan hukum waris islam, dan kitab yang sering digunakan beliau adalah kitab Robbiyah. Berikut beberapa contoh penyelesaian sengketa waris yang diajukan kepada bapak Abdul Fattah:33

Contoh pertama, ibu Marhamah menikah dua kali, pertama dengan Sukarni dan kedua dengan Rahmat. Pada pernikahan pertama, Marahamah memiliki tiga anak perempuan yaitu Ruqoiyyah, Romlah dan Khofifah, dan pada pernikahan kedua Marhamah memiliki satu anak perempuan yang bernama Salbiah. Pada saat Marhamah meninngal dunia, kedua suami Marhamah dan satu anaknya yang bernama Salbiyyah telah meninggal dunia terlebih dahulu. Demikian juga Salbiyah meninggalkan dua anak laki-laki dan tiga anak perempuan. Anak marhamah yang masih hidup adalah Ruqoiyyah, Romlah, dan Khofifah. Namun anak dari Salbiyyah menginginkan bagian dari harta warisan yang ditinggalkan Marhamah, padahal anak-anak Salbiyyah tidak termasuk ahli waris karena ibu mereka yang bernama Salbiyyah meninggal terlebih dahulu.

Dalam kasus ini bapak Suhadi selaku suami Ruqoiyyah datang ke bapak Abdul Fattah dan meminta beliau untuk jadi penengah atau mediator dan menyelesaikan masalah tersebut. Dari proses mediasi tersebut hasil dari kesepakatannya adalah anak-anak Salbiyyah tidak mendapatkan warisan dari nenek mereka Marhamah. Karena dalam hukum waris Islam, anak-anak Salbiyyah terhalang untuk mendapatkan warisan. 34

Contoh kedua: Subadi, Ngabdan, dan Sutimah adalah saudara sebapak dan seibu. Saat ibu mereka meninngal dunia bapak mereka menikah lagi dan memiliki satu anak perempuan yang bernama Sumarni. Pada saat Sutimah meninggal dunia, saudara Sutimah yang bernama Ngabdan telah meninggal dunia terlebih dulu dan meninggalkan tiga anak laki-laki. Dalam kasus ini Subadi kurang paham apakah anak-anak dari Ngabdan dan Sumarni juga

33 Abdul Fattah, Wawancara, Demak 10 Oktober 2018.

34Ibid. 
mendapatkan bagian dari warisan Sutimah. Kemudian Subadi datang ke bapak Abdul Fattah dan meminta beliau menjelaskan dan menyelesaikan masalah tersebut.

Dari musyawarah yang telah disepakati dengan bapak Abdul Fattah sebagai mediator atau penengahnya menghasilkan kesepakatan bahwa anak-anak Ngabdan serta saudara sebapak Sutimah yang bernama Sumarni yang semestinya tidak mendapakatkan warisan dari Sutimah pada kesepakatannya mendapatkan warisan dari Sutimah. Karena Subadi dan ahli waris lainnya sepakat untuk memberikan sebagian harta warisan Sutimah kepada anak-anak Ngabdan dan Sumarni dengan sukarela.35

Adapun proses penyelesaian sengketa pembagian harta warisan sebagai berikut:

1. Salah satu pihak yang bersengketa waris datang ke rumah bapak Abdul Fattah dan menceritakan permasalahan yang sedang terjadi.

2. Bapak Abdul Fattah meminta agar semua ahli waris dan pihak yang bersangkutan untuk berkumpul.

3. Bapak Abdul Fattah menjelaskan bagian-bagian masing ahli waris disertai dengan nasihat-nasihat agar masalah sengketa waris bisa diselesaikan secara musyawarah.

4. Bapak Abdul Fattah memutuskan dan menetapkan kesepakatan yang telah disepakati para pihak yang bersengketa.36

Ketika para pihak telah menyepakati keputusan mediasi, mengenai pembagian harta warisanya dikembalikan lagi pada para pihak oleh bapak Abdul Fattah, namun jika pihak meminta Bapak Abdul Fattah membaginya, Bapak Abdul Fattah hanya sebagai saksi bahwa benar harta warisan yang didapatkan sesuai dengan hasil kesepakatan dari mediasi.

Apabila bapak Abdul Fattah dengan para pihak yang bersengketa tidak menemukan penyelesaian sengketa waris dengan musyawarah para pihak yang bersengkata dianjurkan untuk datang ke Sarekat Desa (perangkat desa).37 Proses penyelesaian sengketa

35 Ibid.

36 Ibid.

37 Ibid. 
waris yang diajukan kepada perangkat desa itu tidak jauh berbeda dengan proses mediasi bersama bapak Abdul Fattah sebagai mediator. Bedanya, ketika Perangkat desa yang menjadi mediator, perangkat desa hanya memberikan surat keterangan, bahwa itu benar bagian yang didapatkan ahli waris untuk balik nama akte tanah.38

\section{Peran Tokoh Masyarakat Desa Wonosalam Kecamatan Wonosalam Kabupaten Demak Sebagai Mediator dalam Penyelesaian Sengketa Waris}

Masayarakat Desa Wonosalam sudah pernah mempelajari ilmu waris, akan tetapi hanya sebatas mempelajari waris Islam, kemudian dalam proses pembagian harta warisan masyarakat masih mempercayakannya kepada tokoh masyarakat setempat yang dirasa mampu dan lebih paham tentang waris, terlebih apabila terjadi perselisihan antara ahli waris yang satu dengan yang lainnya.39

Jadi, tokoh masyarakat Desa Wonosalam memiliki peran yang penting dalam pembagian dan penyelesaian sengketa keluarga. Dalam penyelesaian permasalahan keluarga di antara pihak-pihak yang bersengketa, tokoh masyarakat berperan sebagai mediator atau pihak penengah yang netral dan lebih menekankan pada nilai-nilai keagamaan tentang pentingnya komunikasi dan musyawarah dalam suatu konflik yang terjadi untuk mencegah konflik yang lebih besar lagi.

Di Desa Wonosalam proses penyelesaian sengketa waris melalui mediator tokoh masyarakat bukanlah suatu proses mediasi yang wajib dilaksanakan dan harus melalui proses mediasi bersama tokoh masyarakat, melainkan hanya apabila ada pihak-pihak yang datang atau meminta kepada tokoh masyarakat sebagai mediatornya untuk membantu proses penyelesaian sengketa.40

Masyarakat Desa Wonosalam yang bermediasi kepada tokoh masyarakat sebagian besar adalah mereka yang patuh dan taat terhadap nilai-nilai agama. Oleh sebab itu mereka membutuhkan nasihat dan pengetahuan mengenai agama dan hal itu diperoleh dari

38 Royan (Sekertaris Desa), Wawancara, Demak 24 September 2018.

39 Abdul Fattah,Wawancara, Demak, 24 Sepetember 2018

40 Abdul Fattah, Wawancara, Demak, 24 Sepetember 2018 
seseorang yang tentunya mempunyai pengetahuan agama yang lebih luas dari pada mereka, salah satunya yaitu dari tokoh masyarakat yang mana nantinya diharapkan agar keputusan yang dihasilkan tidak bertentangan dengan ajaran agama dan kebanyakan masyarakat yang datang untuk meminta tokoh masyarakat sebagai mediatornya adalah masyarakat yang memiliki permasalahan kekeluargaan khusunya mengenai pembagian harta waris.

Proses mediasi di Desa Wonosalam sangat jauh berbeda dengan proses mediasi yang berada di pengadilan. Dalam prosedur pelaksanaannya, tidak ada ketentuan-ketentuan khusus yang mengatur, dalam artian tidak mengikuti syarat-syarat mediasi secara formal sebagaimana ditetapkan oleh undang-undang seperti proses mediasi di Pengadilan, melainkan peraturan dan ketentuanketentuan lainnya dalam mediasi ditentukan oleh para pihak, baik waktu maupun proses lainnya. Sedangkan tokoh masyarakat sebagai mediator mengikuti apa yang diinginkan oleh pihak-pihak yang terkait dengan permasalahan sehingga apa yang dipersengketakan dapat diselesaikan dengan baik tanpa ada perselisihan lagi di kemudian hari dan masing-masing pihak dapat menerima kesepakatan secara ikhlas. Dalam proses mediasi ini, hasil keputusannya bukanlah suatu putusan yang bersifat menang kalah, melainkan masing-masing pihak sama-sama menang dan sama-sama rela menerima kesepakatan yang telah disepakati bersama atau sesuai dengan prinsip win-win solution.

Dalam penyelesaian sengketa waris, tokoh masyarakat Desa Wonosalam mengunakan dasar hukum waris Islam saja, artinya tidak menggunakan dasar hukum positif di Indonesia atau Kompilasi Hukum Islam dan hukum waris adat. Karena mayoritas masyarakat Desa Wonosalam kurang begitu paham peraturan hukum waris yang diatur dalam hukum positif di Indonesia dan tidak adanya aturan adat di desa tersebut. Dengan begitu, hukum waris Islam digunakan sebagai dasar hukum dalam pembagian harta waris dan menyelesaikan sengketa waris.

Misalnya dalam pasal 185 Kompilasi Hukum Islam menyatakan:41

41Pasal 185 Kompilasi Hukum Islam. 
1. Ahli waris yang meninggal lebih dahulu dari pada si pewaris maka kedudukannya dapat digantikan oleh anaknya, kecuali mereka yang tersebut dalam pasal 173.

2. Bagian ahli waris pengganti tidak boleh melebihi dari bagian ahli waris yang sederajat dengan yang diganti.

Dalam pasal tersebut diketahui, bahwa dalam hukum positif ada ahli waris pengganti, namun dalam hukum waris Islam apabila ahli waris meninggal lebih dulu maka anak dari ahli waris yang meninggal tersebut terhalang untuk mendapatkan harta waris. Akan tetapi para ahli waris dapat melakukan kesepakatan perdamaian, hal ini sesuai pasal 183 Kompilasi Hukum Islam yang menyatakan: "Para ahli waris dapat bersepakat melakukan perdamaian dalam pembagian harta warisan, setelah masing-masing menyadari bagiannya". 42 Jadi, mendapatkan atau tidaknya harta waris, bagi anak dari ahli waris yang meningal lebih dulu dari pewaris, dapat disepakati untuk melakukan perdamaian terlebih dulu.

Secara singkatnya peran tokoh masyarakat sebagai mediator dalam penyelesaian sengketa waris adalah:

1. Membuka dan memimpin proses mediasi.

2. Menjelaskan dan mentukan bagian-bagian ahli waris.

3. Memberikan nasihat dan solusi yang terbaik.

4. Memutuskan dan menetapkan apa yang telah di sepakati para pihak yang bersengketa.

5. Mencegah timbulnya sengketa yang lebih besar lagi.

6. Tetap menjaga kerukunan dan keharmonisan hidup bermasyarakat.43

Adapun hal-hal yang melatar belakangi berhasilnya suatu proses mediasi yang dilakukan oleh tokoh masyarakat di Desa Wonosalam di antaranya:

1. Mediator memberikan nasihat dan solusi berdasarkan Al Qur'an dan Hadits Rosulullah.

2. Mediator menanamkan pentingnya silaturahmi dan tolong menolong serta saling menghormati antara sesama manusia.

42Pasal 183 Kompilasi Hukum Islam.

43 Abdul Fattah, Wawancara, Demak, 24 Sepetember 2018

66 \begin{tabular}{l|l} 
AL-HUKAMA \\
The Indonesian Journal of Islamic Family Law \\
Volume 09, Nomor 01, Juni 2019
\end{tabular} 
3. Mediator menumbuhkan rasa ikhlas pada diri para pihak dan berusaha untuk saling menerima jugu memaafkan.

4. Mediator mengajak para pihak untuk berfikir jauh kedepan, dengan menggambarkan bahwa akibat dari segketa Waris dapat merusak hubungan kekeluargaan.

5. Itikad baik dari para pihak yang besengketa untuk menyelesaikan sengketa dengan musyawarah secara kekeluargaan.

\section{Kekuatan Hukum Peyelesaian Sengketa Waris Oleh Mediator Tokoh Masyarakat di Desa Wonosalam Kecamatan Wonosalam Demak}

Berdasarkan ketentuan pasal 25 Undang-Undang Nomor 48 Tahun 2009 tentang Kekuasaan Kehakiman yang menyatakan, bahwa badan peradilan yang berwenang untuk memeriksa dan mengadili persengketaan atau perkara perdata adalah peradilan umum dan peradilan agama.44

Dalam hukum positif Indonesia, penyelesaian sengketa dapat diselesaikan melalui jalur litigasi maupun jalur non-litigasi. Jalur litigasi mengarah pada hukum acara yang berlaku dan penyelesaiannya melalui pengadilan berdasarkan pasal 49 UndangUndang Nomor 3 Tahun 2006 tentang Perubahan atas UndangUndang Nomor 7 Tahun 1989 tentang Peradilan Agama yang menyatakan bahwa:

Pengadilan agama bertugas dan berwenang memeriksa, memutus, dan menyelesaikan perkara di tingkat pertama antara orang-orang yang beragama Islam di bidang:

1. perkawinan;

2. waris;

3. wasiat;

4. hibah;

5. wakaf;

6. zakat;

7. infaq;

8. shadaqah; dan

9. ekonomi syari'ah45

44Undang-Undang Nomor 48 Tahun 2009 tentang Kekuasaan Kehakiman. 45Pasal 1 Undang-Undang Nomor 3 Tahun 2006 tentang Peradilan Agama. 
Selain melalui pengadilan (litigasi), penyelesaian sengketa juga dapat diselesaikan di luar pengadilan (non-litigasi) yang lazim dinamakan dengan Alternatif Dispute Resolution (ADR) yang berdasarkan pasal 1 ayat 10 Undang-Undang Nomor 30 tahun 1999 tentangAternatif Penyelesaian Sengketa yang menyatakan bahwa:

Alternatif Penyelesaian Sengketa adalah lembaga penyelesaian sengketa atau beda pendapat melalui prosedur yang disepakati para pihak, yakni penyelesaian di luar pengadilan dengan cara konsultasi, negosiasi, mediasi, konsiliasi, atau penilaian ahli.46

Penyelesaian secara damai merupakan jalan yang terbaik bagi semua pihak, penggunaan jalur litigasi yang panjang dan berbelitbelit pada akhirnya hanya sebagai sarana untuk menunjukkan sikap egois semata. Para pihak yang tetap berkeras menginginkan agar penyelesaiannya diputuskan oleh pengadilan biasanya mengandung konflik non-hukum di luar pokok sengketanya, misalnya diantara para pihak terlibat konflik emosional, dendam dan sentimen pribadi. $\mathrm{Hal}$ inilah yang sering menjadi penghalang terjadinya perdamaian diantara para pihak yang bersengketa.

Dengan adanya mediasi, maka dalam menyelesaikan sengketa diharapkan cepat selesai dan terlaksana dengan baik meskipun tidak semua mediasi dapat berjalan dengan lancar dan sesuai dengan keinginan yang diharapkan, bahkan proses mediasi yang dilakukan bisa gagal.

Sama halnya yang terjadi pada masyarakat di Desa Wonosalam Kecamatan Wonosalam Kabupaten Demak. Apabila terjadi masalah keluarga mereka lebih memilih menyelesaikannya secara kekeluargaan terlebih dahulu. Salah satunya adalah persoalan pembagian warisan. Jika terjadi perselisihan antar ahli waris yang tidak dapat diselesaikan dengan musyawarah keluarga, mereka tidak mengajukan sengketa kewarisan ke Pengadilan Agama. Masyarakat lebih memilih menyelesaikannya melalui tokoh mayarakat dan kemudian diadili dan diputuskan oleh tokoh masyarakat.

Namun, hasil yang telah disepakati para pihak yang bersengketa bersama mediator tokoh masyarakat tidak dikukuhkan dengan pembuatan akta perdamaian ataupun surat perjanjian perdamaian.

46Pasal 1 Undang-Undang Nomor 30 tahun 1999 tentang Alternatif Penyelesaiaan Segketa. 
Pengukuhan yang dimaksudkan adalah untuk mendapatkan kekuatan hukum dan dapat mengikat bagi para pihak yang bersengketa dari kesepakatan perdamaian. Hal ini sesuai dengan pasal 27 Peraturan Mahkamah Agung Nomor 1 Tahun 2016 tentang Prosedur Mediasi di Pengadilan yang menyatakan bahwa:

1. Jika Mediasi berhasil mencapai kesepakatan, Para Pihak dengan bantuan Mediator wajib merumuskan kesepakatan secara tertulis dalam Kesepakatan Perdamaian yang ditandatangani oleh Para Pihak dan Mediator.

2. Dalam membantu merumuskan Kesepakatan Perdamaian, Mediator wajib memastikan Kesepakatan Perdamaian tidak memuat ketentuan yang:

a. bertentangan dengan hukum, ketertiban umum, dan/atau kesusilaan;

b. merugikan pihak ketiga; atau

c. tidak dapat dilaksanakan.

3. Dalam proses Mediasi yang diwakili oleh kuasa hukum, penandatanganan Kesepakatan Perdamaian hanya dapat dilakukan apabila terdapat pernyataan Para Pihak secara tertulis yang memuat persetujuan atas kesepakatan yang dicapai.

4. Para Pihak melalui Mediator dapat mengajukan Kesepakatan Perdamaian kepada Hakim Pemeriksa Perkara agar dikuatkan dalam Akta Perdamaian.

5. Jika Para Pihak tidak menghendaki Kesepakatan Perdamaian dikuatkan dalam Akta Perdamaian, Kesepakatan Perdamaian wajib memuat pencabutan gugatan.

6. Mediator wajib melaporkan secara tertulis keberhasilan Mediasi kepada Hakim Pemeriksa Perkara dengan melampirkan Kesepakatan Perdamaian.47

Selanjutnya dalam pasal 1851 KUH Perdata dinyatakan bahwa: "Perdamaian adalah suatu persetujuan yang berisi bahwa dengan menyerahkan, menjanjikan atau menahan suatu barang, kedua belah pihak mengakhiri suatu perkara yang sedang

47Pasal 27 Peraturan Mahkamah Agung Nomor 1 Tahun 2016 tentang Prosedur Mediasi. 
diperiksa pengadilan ataupun mencegah timbulnya suatu perkara bila dibuat secara tertulis." 48

Pengertian tertulis disini tidak hanya dituangkan dalam bentuk akta otentik, dapat saja kesepakatan perdamaian tersebut dituangkan dengan akta di bawah tangan. Kemudian Surat Perdamaian tersebut ditandatangani oleh para pihak yang bersengketa dan saksi yang turut menyaksikan proses penyelesaian sengketa tersebut.

Dari pasal 27 Peraturan Mahkamah Agung Nomor 1 Tahun 2016 tentang Prosedur Mediasi di Pengadilan dan pasal 1851 BW pasal $1851 \mathrm{KUH}$ Perdata menjelaskan apabila proses mediasi telah mencapai kesepakatan perdamaian para pihak yang bersengketa diminta untuk mengukuhkan hasil dari kesepakatan yang telah disepakati dengan mengajukan kesapakatan perdamaian ke Pengadilan atau dengan membuat surat perdamaian secara tertulis yang ditandatangani oleh para pihak yang bersengketa juga saksi yang turut menyaksikan proses perdamaian.

Dengan adanya akta perdamaian atau surat perdamaian maka hasil dari kesepakatan perdamaian tersebut mendapat kepastian hukum. Bahkan dengan dikuatkan kesepakatan damai dalam akta perdamaian, maka kesepakatan perdamaian itu memiliki kekuatan eksekutorial atau memiliki kekuatan hukum sama dengan putusan pengadilan.

Jadi dapat disimpulkan, bahwa kesepakatan perdamaian yang telah disepakati oleh para pihak yang bersengketa melalui mediator tokoh masyarakat di Desa Wonosalam tentang sengketa waris tidak memiliki kekuatan hukum, baik sesuai Peraturan Makaamah Agung Nomor 1 Tahun 2016 tentang Prosedur Mediasi di Pengadilan ataupun hukum perdata.Karena tidak adanya surat perjanjian damai ataupun akte perdamaian.

Apabila para pihak yang bersengketa menginginkan sebuah akta perdamaian yang otentik yang memiliki kekuatan hukum, para pihak yang bersengketa dapat mengajukan akta perdamaian ke pengadilan, hal ini berdasarkan pasal 36 Peraturan Mahkamah Agung Nomor 1 Tahun 2016 tentang Prosedur Mediasi di Pengadilan, yang menyatakan bahwa:

48 Subekti dan Tjitrosudibio, Kitab Undang-undang Hukum Perdata., 420. 
1. Para Pihak dengan atau tanpa bantuan Mediator bersertifikat yang berhasil menyelesaikan sengketa di luar Pengadilan dengan Kesepakatan Perdamaian dapat mengajukan Kesepakatan Perdamaian kepada Pengadilan yang berwenang untuk memperoleh Akta Perdamaian dengan cara mengajukan gugatan.

2. Pengajuan gugatan sebagaimana dimaksud pada ayat (1) harus dilampiri dengan Kesepakatan Perdamaian dan dokumen sebagai alat bukti yang menunjukkan hubungan hukum Para Pihak dengan objek sengketa.

3. Hakim Pemeriksa Perkara di hadapan Para Pihak hanya akan menguatkan Kesepakatan Perdamaian menjadi Akta Perdamaian, jika Kesepakatan Perdamaian sesuai dengan ketentuan Pasal 27 ayat (2).

4. Akta Perdamaian atas gugatan untuk menguatkan Kesepakatan Perdamaian sebagaimana dimaksud pada ayat (1) harus diucapkan oleh Hakim Pemeriksa Perkara dalam sidang yang terbuka untuk umum paling lama 14 (empat belas) hari terhitung sejak gugatan didaftarkan.

5. Salinan Akta Perdamaian sebagaimana dimaksud pada ayat (4) wajib disampaikan kepada Para Pihak pada hari yang sama dengan pengucapan Akta Perdamaian.49

Para pihak yang bersengketa yang menggunakan mediasi di luar pengadilan wajib melaksanakan ketentuan pasal 36 Peraturan Mahkamah Agung Nomor 1 Tahun 2016 tentang Prosedur Mediasi di Pengadilan untuk mengukuhkan kesepakatan perdamaian yang disepakati menjadi akta perdamaian.

Untuk memperoleh akta perdamaian bagi kesepakatan perdamaian di luar pengadilan dengan pengajuan gugatan mungkin dapat dipandang agak aneh. Jika melihat keadaan empiris, bahwa tidak semua orang yang telah mengikat perjanjian dengan pihak lainnya bersedia menaati perjanjian itu, maka pengaturan ini memiliki dasar rasional, mengapa tetap diperlukan syarat melalui pengajuan gugatan padahal para pihak telah berdamai.

Karena pengadilan terikat pada aturan prosedural dalam sistem hukum Indonesia, bahwa pengadilan hanya dapat menjalankan

49Pasal 36 Peraturan Mahkamah Agung Nomor 1 Tahun 2016 tentang Prosedur Mediasi. 
fungsinya atas dasar adanya gugatan untuk sengketa-sengketa dan adanya permohonan untuk masalah hukum yang bukan sengketa.50

Meski dalam penyelesaian sengketa waris di Desa Wonosalam melalui mediator tokoh masyarakat tidak dikukuhkan dalam akta perdamaian dan dalam bentuk surat perdamaian seperti yang telah dijelaskan di atas, selama ini kesepakatan yang telah disepakati antara pihak yang bersengketa bersama mediator tokoh masyarakat masih dijalankan dengan baik kesepakatannya, artinya tidak ada permasalahan dan perdebatan yang timbul kembali dari kesepakatan tersebut.

Selanjutnya untuk meningkatkan kualitas dan hasil dari mediasi oleh mediator tokoh masyarkat dalam menyelesaikan sengketa keluarga khususnya sengketa waris, hendaknya lembaga sertifikasi mediator mengadakan sosialisasi dan pelatihan kepada tokoh masyarakat yang mana hasil dari mediasi yang dilakukan bersama tokoh masyarkat lebih banyak yang berakhir damai dan berhasil.

\section{Penutup}

Tokoh masyarakat Desa Wonosalam Kecamatan Wonosalam Kabupaten Demak memiliki peran penting dalam penyelesaian sengketa waris yaitu sebagai mediator, diantaranya: membuka dan memimpin proses mediasi, menjelaskan dan mentukan bagianbagian ahli waris, memberikan nasihat dan solusi yang terbaik, memutuskan dan menetapkan apa yang telah disepakati para pihak yang bersengketa, mencegah timbulnya sengketa yang lebih besar lagi, dan tetap menjaga kerukunan dan keharmonisan dalam hidup bermasyarakat.

Penyelesaian sengketa waris melalui mediator tokoh masyarakat di Desa Wonosalam tersebut tidak mempunyai kekuatan hukum yang eksekutorial, karena tidak dikukuhkan dengan pembuatan akta perdamaian ataupun surat perjanjian perdamaian, yang tertuang dalam pasal 27 Peraturan Mahkamah Agung Nomor 1 Tahun 2016 dan pasal 1851 KUH Perdata. Meski demikian, ketetapan tokoh masyarakat sebagai mediator dalam penyelesaian sengketa waris tersebut dipatuhi dan dilaksanakan oleh masyarakat Desa Wonosalam Kecamatan Wonosalam Kabupaten Demak.

50 Takdir Rahmadi, Mediasi Penyelesaian ..., 194.

\footnotetext{
$72 \begin{aligned} & \text { AL-HUKAMA } \\ & \text { The Indonesian Journal of Islamic Family Law } \\ & \text { Volume 09, Nomor 01, Juni } 2019\end{aligned}$
} 


\section{Daftar Pustaka}

Abdul Fattah. Wawancara, Demak, 17 September 2018.

---. Wawancara, Demak, 10 Oktober 2018.

-----. Wawancara, Demak, 24 September 2018.

Alimuddin Tuwu. Pengantar Metode Penelitian. Jakarta: UI-Press, 1993. Amarullah Umar Kadafi. "Tinjauan Hukum Islam terhadap Kebiasaan Masyarakat dalam Pembagian Waris di Kejawan Lor Kelurahan Kenjeran Kecamatan Bulak Surabaya", Penelitian--IAIN Sunan Ampel, Surabaya, 2009.

Amin Husein Nasution. Hukum Kewarisan: Suatu Analisis Komparatif Pemikiran Mujtahid dan Kompilasi Hukum Islam. Jakarta: Raja Grafindo Persada, 2012.

Amir Syarifuddin. Hukum Kewarisan Islam.Jakarta: Prenada Media, 2004.

Cholid Narbuko dan Abu Achmadi. Metodologi Penelitian. Jakarta: PT Bumi Aksara, 2009.

Fatchur Rachman. Ilmu Waris. Bandung: PT Al-Ma'arif, 1975.

Harijah Darmis. "Hukum Mediasi Versi Sema Nomor 1 Tahun 2002 tentang Pemberdayaan Pengadilan Tingkat Pertama Menerapkan Lembaga Damai”.Mimbar Hukum, Nomor 63, Maret-April, 2004.

Hazairin. Hukum Kewarisan Bilateral Menurut Qur'an dan Hadits Jakarta: Tintamas,1982.

Jalil.Wawancara, Demak 15 September 2018.

Kaelan. Metode Penelitian Agama Kualitatif Interdsipliner. Yogyakarta: Paradigma, 2010.

M. Muhibbin dan Abdul Wahid. Kewarisan Islam Sebagai Pembaharuan Hukum Positif di Indonesia,cet.2. Jakarta: Sinar Grafika, 2011.

Ma'ruf Jauhari. "Perdamaian Ahli Waris dalam Pembagian Harta Warisan, Studi Analisis Terhadap Pasal 183 Kompilasi Hukum Islam di Indonesia".Penelitian--IAIN Sunan Ampel, Surabaya, 2000.

Mansyur, Achmad. “Tinjauan Hukum Islam Terhadap Pelaksanaan Pembagian Harta Waris Di Desa Sedati Agung Kecamatan Sedati Kabupaten Sidoarjo".Penelitian--UIN Sunan Kalijaga, Yogyakarta, 2008. 
Peraturan Mahkamah Agung Nomor 1 Tahun 2016 Tentang Prosedur Mediasi di Pengadilan.

Poerwadarminta. Kamus Umum Bahasa Indonesia.Jakarta: Balai Pustaka, 2005.

Rachmadi Usman. Piliban Penyelesaian Sengketa di Luar Pengadilan. Bandung: PT. Citra Aditya Bakti, 2003.

Raco, J.R. Metode Penelitian Kualitatif: Jenis, Karakteristik, dan Keunggulannya. Jakarta: Grasindo, 2010.

Restiana. "Penyelesaian Sengketa Tanah Warisan Melalui Mediasi Studi Kasus di Pengadilan Agama Watampone Kelas 1B".Penelitian--UIN Alauddin, Makasar, 2016.

Royan. Wawancara. Demak, 24 September 2018.

Salman, Otje dan Mustofa Haffas.Hukum Waris Islam.Bandung: PT Refika Adita, 2014.

Soerjono Soekanto. Sosiologi Suatu Pengantar. Jakarta: Rajawali Pers, 1990.

Subekti dan Tjitrosudibio. Kitab Undang-undang Hukum Perdata. Jakarta: Pradnya Paramita, 1985.

Subekti. Aneka Perjanjian.Bandung: PT. Citra Aditya Bakti, 1995.

Suhrawardi K Lubis dan Komis Simanjutak. Hukum Waris Islam, Jakarta: Sinar Grafika, 2007.

Suparman Usman dan Yusuf Somawinata.Fiqh Mawaris. Jakarta: Gaya Media Pratama, 2002.

Suyut Margono. ADR dan Arbitrase Proses Pelembagaan dan Aspek Hukum. Bogor: PT. Graha Indonesia, 2000.

Syahrizal Abbas. Mediasi Dalam Perspektif Hukum Syariah, Hukum Adat, dan Hukum Nasional, cet.1. Jakarta: Kencana Prenada Media, 2009.

Takdir Rahmadi. Mediasi Penyelesaian Sengketa Melalui Pendekatan Mufakat. Jakarta: Raja grafindo Persada, 2011.

Tim Penyusun Kamus Pusat Bahasa.Kamus Besar Bahasa Indonesia. Edisi Ketiga, cet.2. Jakarta: Balai Pustaka, 2002.

Tim Redaksi Nuansa Aulia.Kompilasi Hukum Islam,cet.3. Bandung: CV Nuansa Aulia, 2011.

Undang-Undang Nomor 1 Tahun 1974 Tentang Perkawinan. Undang-Undang Nomor 3 Tahu 2006 Tentang Peradilan Agama. 
Undang-Undang Nomor 30 Tahun 1999 Tentang Alternatif Penyelesaiaan Sengketa.

Undang-Undang Nomor 48 Tahun 2009 Tentang Kekuasaan Kehakiman.

Victor M Situmorang. Perdamaian dan Perwasitan dalam Hukum Acara Perdata.Jakarta: Rineka Cipta, 1993.

Whimbo Pitoyo. Strategi Jitu Memenangi Perkara Perdata Dalam Praktik Peradilan. Jakarta: Visimedia, 2012.

Wirjono Prodjodikoro. Hukum Perdata Tentang Persetujuan-Persetujuan Tertentu. Bandung: Vorkink-van Hoeve, 1959.

Yusna Zaidah. Penyelesaian Sengketa Mealui Peradilan dan Arbirtase Syariah di Indonesia, cet.2. Yogyakarta: Aswaja Pressindo, 2015. 